Jurnal Keperawatan Silampari

Volume 3, Nomor 1, Desember 2019

e-ISSN: 2581-1975

p-ISSN: 2597-7482

DOI: https://doi.org/10.31539/jks.v3i1.821

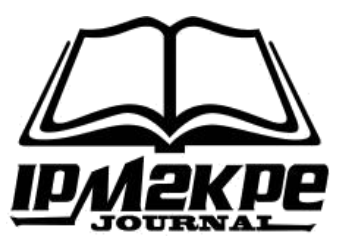

\title{
EFEKTIFITAS FOOT SPA DIABETIC TERHADAP NILAI ANKLE BRACHIAL INDEX PADA PASIEN DIABETES MELITUS TIPE II
}

\author{
Rizkan Halalan Djafar ${ }^{1}$, Busjra M. Nur ${ }^{2}$, Rohman Azzam ${ }^{3}$ \\ Program Studi Ilmu Keperawatan, STIKES Muhammadiyah Manado ${ }^{1}$ \\ Program Studi Magister Keperawatan, Universitas Muhammadiyah Jakarta ${ }^{2,3}$ \\ ns.rizkandjafar@gmail.com ${ }^{1}$
}

\begin{abstract}
ABSTRAK
Tujuan dari penelitian ini adalah untuk mengetahui efektivitas foot spa diabetic terhadap nilai ABI pada pasien diabetes mellitus tipe II. Desain penelitian menggunakan quasy-experiment two group. Hasil analisa dengan uji Mann-Whitney diperoleh ada perbedaan yang signifikan nilai ABI sebelum dan setelah di beri intervensi foot spa diabetic selama 5 hari dan 3 hari yaitudengan $\mathrm{P}=0.112>\alpha(0,05)$, dengan rata rataselisih nilai ABI pada kelompok intervensi 3 hari dan kelompook intervensi 5 hari pada saat pre test 0.012 dan post test 0.0562 . Simpulan, foot spa diabetic selama 3 dan 5 hari efektif meningkatkan nilai ABI.
\end{abstract}

Kata Kunci: Ankle Brachial Index, DM Tipe 2, Foot Spa Diabetic

\begin{abstract}
The purpose of this study is to find out the effectiveness of diabetic foot spa towards ankle brachial index. Design of this study is Quasy-Experiment with two group. The population were all diabetes mellitus patients type 2 in Public Health Centre Wawonasa Manado. Number of sample was 32 person, divided into 2 group, that are treatment group during 3 and 5 time, with 16 person each group, taken by purposive sampling technique. Data analyzed by Mann-Whitney test with $\alpha=0.05$. Study results on difference between ABI treatment 3 dan 5 time. Analysis of Mann-Whitney test $P=0.112>\alpha=0.05$, with average ABI in treatment group during 3 and 5 time pre test 0.012 and post test 0.0562, which means diabetic foot spa 3 and 5 time is effective towards $A B I$.
\end{abstract}

Keywords: Ankle Brachial Index, DM Type 2, Foot Spa Diabetic

\section{PENDAHULUAN}

Pravalensi dan insidensi penderita DM tipe 2 meningkat secara signifikan dari tahun ke tahun,penyakit ini menjadi sebuah ancaman kesehatan global (PERKENI, 2015). Studi populasi Diabetes Mellitus tipe 2 di berbagai negara melaporkan bahwa jumlah penderita DM di dunia telah mencapai 425 juta jiwa, dimana prevalensi diabetes cenderung lebih tinggi pada pria (221 juta jiwa) dibanding wanita (204 juta jiwa). Angka kematian akibat dari DM yang dilaporkan adalah sebesar 4 juta jiwa, diprediksi jumlah penderita DM Pada tahun 2045 mengalami peningkatan yang mencapai 629 juta 
jiwa.Amerika Serikat menempati urutan ketiga dunia dengan pravalensi penderita diabetes melitus 30,2 juta jiwa. Tahun 2045 diperkirakan terjadi peningkatan 35,6 juta jiwa. Di Asia timur negara cina menempati posisi tertinggi pertama dunia dengan jumlah penderita diabetes melitus sebanyak 114,4 juta jiwa. Pada tahun 2045 diperkirakan meningkat 134,3 juta jiwa (IDF, 2017). Indonesia menempati urutan ke 6 sebagai negara dengan jumlah penderita DM terbanyak didunia setelah China, India, United States, Brazil dan Mexico. Berdasarkan area geografis, sebaran penderita DM terbanyak adalah diwilayah DI Yogyakarta sebanyak 2,6\%, disusul oleh DKI Jakarta 2,5\%, dan Sulawesi Utara sebanyak 2,4\% (Riset Kesehatan Dasar, 2013; Jumari, 2019). Prevalensi dengan penderita DM pada tahun 2017 adalah 425 juta orang. Indonesia menempati urutan ke-6 (IDF, 2017). DM tipe 2 merupakan jenis DM yang paling sering terjadi, mencakup sekitar 85\% pasien DM (Greenstain, Wood, 2010). DM tipe 2 bisa menyebabkan berbagai komplikasi pada penderitanya, baik akut maupun kronik. Salah satu komplikasi kronik yang banyak terjadi adalah Peripheral Arterial Disease (PAD) dan neuropati sensorik maupun motorik. Hampir $60 \%$ penderita mengalami komplikasi tersebut (Black \& Hawks, 2014).

Komplikasi PAD dan neuropati disebabkan oleh penurunan sirkulasi darah perifer hingga ke serabut saraf, menyebabkan penderita DM mudah mengalami luka gangren. Faktor resiko yang mudah terjadi pada PAD adalah aterosklerosis yang meliputi: ras, jenis kelamin, bertambahnya usia, merokok, DM, hipertensi, dyslipidemia, keadaan hiperkoagulitas dan hipervisikositas, hiperhomosistemia, kondisi inflamasi sistemik dan insufisiensi ginjal kronis (Habibie, 2017). Intervensi yang bisa dilakukan untuk mencegah atau memperlambat komplikasi tersebut dikembangkan melalui penelitian, antara lain senam kaki dan massase kaki.

Pada pasien DM, hiperglikemia kronis memicu glikosilasi nonenzimatik dan peningkatan difusi glukosa pada jaringan yang tidak memerlukan insulin seperti saraf, dan pembuluh darah. Glikosilasi nonenzimatik pada pembuluh darah mengakibatkan terbentuknya irreversible advanced glycosylation end products (AGEs) sehingga terjadi kelainan struktur dan fungsi kapiler (Subekti, 2014).

Berbagai upaya dilakukan untuk mencegah dan mengontrol terjadinya komplikasi dalam penatalaksanaan DM. Perawatan kaki adalah salah satu faktor yang dapat mempengaruhi nilai $\mathrm{ABI}$. foot spa diabeticmerupakan serangkaian kegiatan perawatan kaki yang di dalamnya terdapat kegiatan senam kaki, pembersihan dengan air hangat, dan pemijatan (Purwanto, 2014). Kegiatan-kegiatan tersebut selain dapat melancarkan aliran darah, juga membuat pasien merasa nyaman dan rileks. Beberapa penelitan menjelaskan bahwa ada dua pandangan yang berbeda antara foot spa diabetic sebanyak 5 kali seminggu dan rendam kaki dengan air hangat selama 3 kali dalam seminggu dapat meningkatkan nilai ABI dan juga ada beberapa factor yang belum di teliti yaitu masalah confounding dari variabel dari tindakan foot spa.

\section{METODEPENELITIAN}

Desain penelitian yang digunakan adalah quasi eksperiment pre and post two group design, dengan memberikan perlakuan pada kelompok intervensi 3 dan 5 hari. populasi dalam penelitian adalah semua pasien DM di daerah kerja Puskesmas Wawonasa. Pasien yang diikutsertakan dalam penelitian ini adalah Diabetisi yang berada di daerah kerja Puskesmas Wawonasa, diabetis baik perempuan maupun lakilaki, usia di atas 35 tahun, tidak memiliki gangren, keadaan sadar penuh, mampu berkomunikasi dengan baik dan jelas, serta koperatif, mendapat informasi tindakan dan 
memberikan persetujuan tindakan (informed consent). Sementara yang memiliki luka ganggren, nilai $\mathrm{ABI}$ normal, nilai $\mathrm{ABI}<0.7$, mengalami kelemahan fisik serta penurunan kesadaran, tidak koperatif, sesak nafas, tidak bersedia menjadi responden maka tidak diikutsertakan dalam penelitian ini. Besar sampel 32 orang, dibagi 2 kelompok yaitu intervensi 3 dan 5 hari, masing-masing 16 orang diambil dengan teknik purposive sampling, dilakukan di Puskesmas Wawonasa, pengumpulan data dilakukan pada bulan Februari - Mei 2019, pengambilan dan pengumpulan data menggunakan lembar Kuesioner, observasi pengukuran nilai ABI, Instrumen Pengukuran ABI, SPO foot spa diabetic dan SPO pengukuran ABI. Peneliti melakukan intervensi foot spa diabetic selama 3 kali dalam seminggu pada kelompok 1 dan foot spa diabetic selama 5 kali dalam seminggu pada kelompok 2, Analisa data dilakukan secara univariat, bivariat, menggunakan uji wilcoxon dan mann whitney.

Enrollment

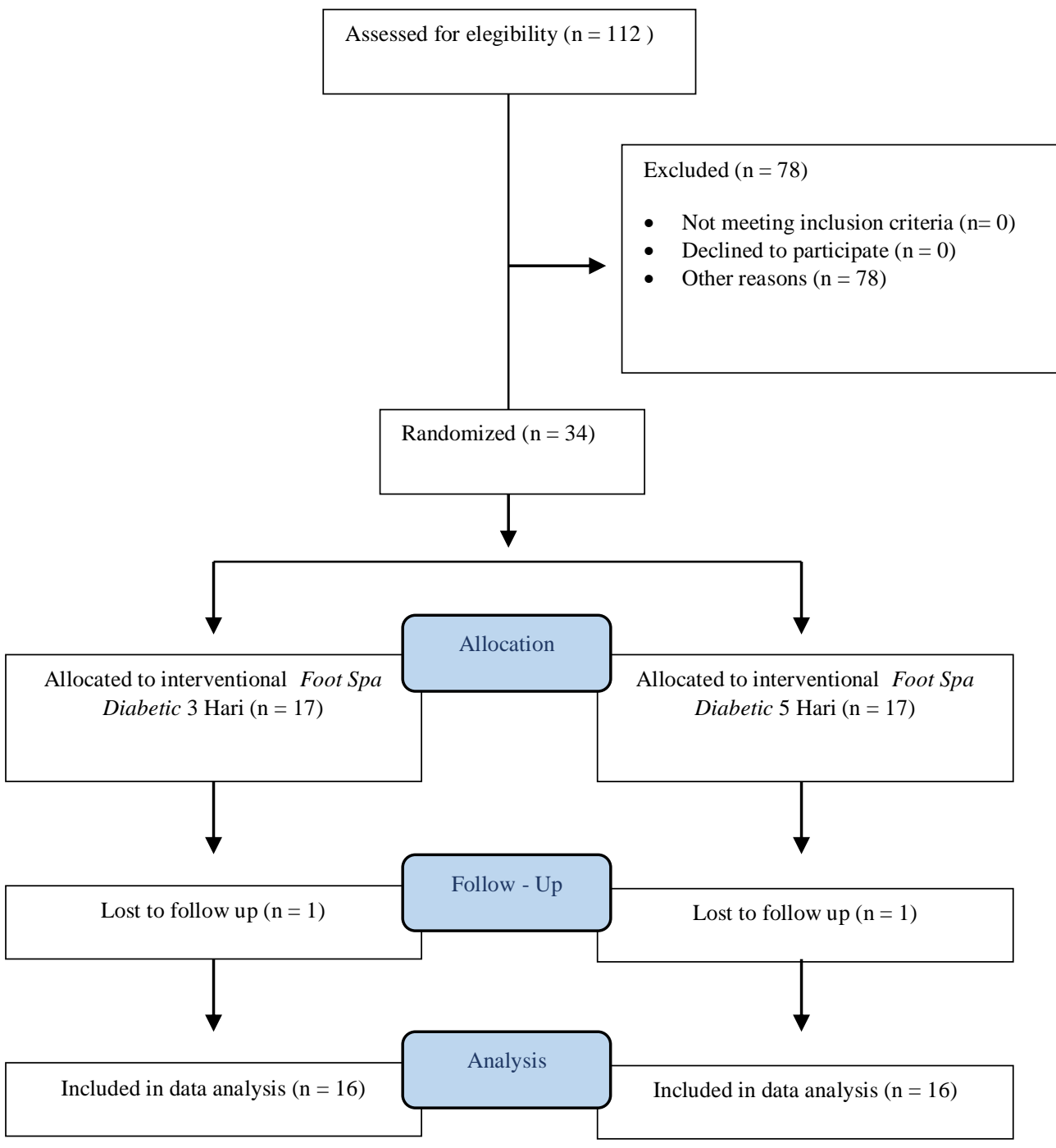

Figure. 1

Flow diagram of trial for two studies 
HASIL PENELITIAN

Karakteristik Responden

Tabel. 1

Karakteristik Responden

\begin{tabular}{lcccc}
\hline \multicolumn{1}{c}{ Variabel } & \multicolumn{2}{c}{ Intervensi 3 Hari } & \multicolumn{2}{c}{ Intervensi 5 Hari } \\
& $\mathrm{n}$ & Presentase $(\%)$ & $\mathrm{n}$ & Presentase (\%) \\
Jenis Kelamin & & & & $18.8 \%$ \\
Laki - laki & 5 & $31.3 \%$ & 3 & $81.3 \%$ \\
Perempuan & 11 & $68.8 \%$ & 13 & \\
\hline Riwayat Hipertensi & & & & \\
Ya & 12 & $75 \%$ & 13 & $81.3 \%$ \\
Tidak & 4 & $25 \%$ & 3 & $18.8 \%$ \\
& 6 & $37.5 \%$ & 5 & $31.3 \%$ \\
Merokok & 10 & $62.5 \%$ & 11 & $68.8 \%$ \\
Ya & & & & \\
Tidak & 6 & $37.5 \%$ & 7 & $43.8 \%$ \\
\hline Shalat 5 Waktu & 10 & $62.5 \%$ & 9 & $56.3 \%$ \\
Ya & & & & \\
Tidak & & & & \\
\hline
\end{tabular}

Berdasarkan tabel 1 Karakteristik responden menunjukan bahwa berdasarkan jenis kelamin kelompok intervensi 3 hari diketahui sebagian besar $(68.8 \%)$ perempuan dan kelompok intervensi 5 hari sebagian besar $(81.3 \%)$ perempuan, berdasarkan riwayat hipertensi kelompok intervensi 3 hari sebagian besar ya (75\%) dan kelompok intervensi 5 hari sebagian besar ya $(81.3 \%)$, berdasarkan merokok kelompok intervensi 3 harisebagian besar (62.5\%)tidak dan kelompok intervensi 5 hari sebagian besar $(68.8$ $\%$ ) tidak, berdasarkan shalat 5 waktu intervensi 3 hari sebagian besar $62.5 \%$ tidak dan kelompok intervensi 5 hari sebagian besar $56.3 \%$ tidak, berdasarkan usia intervensi 3 hari rata - rata usia 56 tahun dan kelompok intervensi 5 hari rata - rata usia 60 tahun, berdasarkan lama mendertia DM intervensi 3 hari rata - rata 5 tahun dan kelompok intervensi 5 hari rata - rata 5 tahun.

\section{Analisa Univariat}

Rata - rata nilai ABI sebelum intervensi pada kelompok intervensi 3 hari hari rata - rata 0.8687. Sedangkan rata - rata nilai ABI setelah intervensi pada kelompok intervensi 5 hari rata - rata 0.9063. Rata - rata nilai ABI sebelum intervensi pada kelompok intervensi 5 hari rata - rata 0.8375. Sedangkan rata - rata nilai ABI setelah intervensi pada kelompok intervensi 5 hari rata - rata 0.9625 .

\section{Analisa Bivariat}

Tabel. 2

Perbedaan Rata - Rata Nilai ABI Sebelum dan Sesudah pada Kelompok Intervensi 3 dan 5 Hari

\begin{tabular}{ccccc}
\hline & \multicolumn{5}{c}{ Intervensi 3 Hari } \\
\hline Pengukuran & Mean & Standart Deviasi & Min - Max & P Value \\
\hline Sebelum & 0.8687 & 0.13525 & $0.7-1.3$ & \multirow{2}{*}{0.058} \\
\hline Sesudah & 0.9063 & 0.12366 & $0.7-1.2$ & \\
\hline
\end{tabular}




\begin{tabular}{ccccc}
\hline & \multicolumn{5}{c}{ Intervensi 5 Hari } \\
\hline Pengukuran & Mean & Standart Deviasi & Min - Max & P Value \\
\hline Sebelum & 0.8375 & 0.15438 & $0.7-1.3$ & \multirow{2}{*}{0.001} \\
\hline Sesudah & 0.9625 & 0.08851 & $0.7-1.2$ & \\
\hline
\end{tabular}

Hasil tabel 2 intervensi 3 hari didapatkan rata - rata nilai ABI sebelum intervensi adalah 0.8687 dan sesudah intervensi adalah 0.9063. Hasil uji wilcoxon diperoleh $\mathrm{p}$ value $(0.058)>\alpha(0.05)$ artinya tidak ada perbedaan yang signifikan nilai ABI sebelum dan sesudah intervensi foot spa diabetic selama 3 hari. Intervensi 5 hari didapatkan rata - rata nilai ABI sebelum intervensi adalah 0.8375 dan sesudah intervensi adalah 0.9625 . Hasil uji Wilcoxondiperoleh P Value $(0.001)<\alpha(0.05)$ maka Ho artinya ada perbedaan yang signifikan nilai ABI sebelum dan sesudah intervensi foot spa diabetic selama 5 hari.

Tabel. 3

Perbedaan Rata - Rata Nilai ABI Sebelum dan Sesudah pada Kelompok Intervensi 3 dan 5 hari

\begin{tabular}{ccccc}
\hline \multirow{2}{*}{ Kelompok } & \multicolumn{2}{c}{ Sebelum } & \multicolumn{2}{c}{ Sesudah } \\
\cline { 2 - 5 } & Mean & Min - Max & Mean & Min - Max \\
\hline 3 Hari & 0.8687 & $0.70-1.30$ & 0.9063 & $0.70-1.20$ \\
\hline 5 Hari & 0.8375 & $0.70-1.30$ & 0.9625 & $0.70-1.20$ \\
\hline $\begin{array}{c}\text { Uji Mann- } \\
\text { Whitney }\end{array}$ & \multicolumn{2}{c}{ Pvalue $=0.408$} & Pvalue $=0.112$ \\
\hline
\end{tabular}

Hasil uji Mann-Whitney sebelum pada kelompok intervensi 3 hari diperoleh $\mathrm{P}$ value $=0.408>\alpha(0.05)$, tidak ada perbedaan yang signifikan rata - rata nilai $\mathrm{ABI}$ sebelum intervensi pada kelompok intervensi 3 dan 5 hari. Hasil uji pada sesudah intervensi pada kelompok intervensi 3 dan 5 hari dengan hari diperoleh p value $=0.112$ $>\alpha(0.05)$, tidak ada perbedaan yang signifikan rata - rata nilai ABI setelah pada kelompok intervensi 3 dan 5 hari.

\section{PEMBAHASAN}

\section{Analisa Perbedaan Nilai ABI Sebelum dan Setelah Intervensi pada Kelompok Intervensi 3 Hari}

Hasil analisis pada kelompok intervensi didapatkan bahwa rata-rata nilai ABI sebelum adalah 0.8687 dan sesudah adalah 0.9063 dengan rata-rata perubahan 0.067 . Hasil uji Wilcoxon diperoleh $\mathrm{P}$ value $(0.058)>\alpha(0,05)$ maka Ho diterima artinya tidak ada perbedaaan nilai ABI darah sebelum dan sesudah pada kelompok intervensi. Hal tersebut dikarenakan ada responden yang merokok, riwayat hipertensi dan tidak menjaga pola makannya terhadap makanan manis dan berlemak. Menurut Black and Hawks (2014) rokok adalah vasokonstriktor kuat sehingga mengganggu aliran darah ke ekstremitas. Hal tersebut membuat seorang perokok rentan mengalami penurunan sirkulasi darah perifer. Pola makan yang dimaksud adalah tidak mengontrol makanan dan minuman yang mengandung gula tinggi serta makanan-makanan berlemak. Makanan dan minuman dengan kadar gula tinggi tentu akan menyebabkan kadar gula darah meningkat, sehingga orang dengan pola makan yang tidak terkontrol lebih rentan terhadap gangguan pada sirkulasi darahnya. Seperti pendapat dari Ariska (2019) yang 
menyatakan bahwa pola makan yang baik tanpa di barengi dengan transport glukosa kedalam sel dapat menyebabkan penumpukan glukosa di dalam darah sehingga kadar gula darah pasien DM menjadi tidak terkontrol.

Kadar glukosa darah yang tinggi mempunyai dampak negatif yang luas bukan hanya pada metabolisme karbohidrat, tetapi juga terhadap metabolisme protein dan lemak. Akibatnya dapat terjadi aterosklerosis pada jaringan, terutama daerah perifer di tungkai. Glukosa darah yang tinggi mempercepat proses aterosklerosis pada pembuluhpembuluh darah besar seperti aorta, arteri koroner, atau arteri yang memasok darah ke kaki dan otak. Untuk menjaga sirkulasi darah supaya tetap lancar yaitu dengan pola hidup sehat, seperti rutin berolahraga, mengurangi makanan berlemak, berhenti merokok, mengatasi stress dan cukup istirahat. Salah satu cara untuk menigkatkan sirkulasi darah yaitu dengan foot spa diabetic yang terdiri dari berbagai macam kegiatan yaitu senam kaki diabetik sebelum pelaksanaan spa kaki, skin cleansing yaitu pembersihan dengan menggunakan sabun mandi bayi yang lembut dan ringan, pedicure yaitu pemotongan dan pengikisan kuku jika responden memiliki kuku yang sedang panjang dan terakhir adalah foot massage yaitu pemijatan superfisial pada kaki untuk meningkatkan sirkulasi darah (Affiani, 2017).

Menurut Paul (2014) menyatakan bahwa senam kaki sebagai salah satu latihan fisik merupakan strategi tindakan intervensi yang efektif untuk mencegah PAD. Terbukti secara signifikan pada penelitian Harefa (2011) terhadap 29 pasien DM tipe 2 di RSU Dr.Pirngadi Medan, hasil penelitian menunjukkan ada pengaruh yang signifikan senam kaki terhadap sirkulasi darah kaki dengan nilai $p$ value $=0,000(<0,05)$. Latihan intensitas sedang dapat menyebabkan pemulihan fungsi saraf perifer dengan menghambat reduktase aldosa (AR) yang mengarah ke menurunnya NADPH (Nicotinamide Adenine Dinucleotide Fosfat Hidroksida). Penurunan NADPH dapat berkontribusi dalam meningkatkan sintesis nitrat oksida (NO) yang akan menghilangkan hipoksia pada saraf. Peningkatan endotel berasal NO juga dapat menyebabkan pemulihan fungsi saraf pada pasien DPN. Tindakan senam kaki diabetik dapat meningkatkan nitrat oksida dan penghambatan produksi berlebihan protein kinase C (Suyanto, 2017).

Pada saat kegiatan skin cleansing (pembersihan), kaki klien direndam dengan menggunakan air hangat, kegiatan rendam kaki air hangat dapat dilakukan oleh pasien diabetes mellitus yang kurang melalukan aktivitas fisik untuk mencegah terjadinya komplikasi kaki. Merendam bagian tubuh kedalam air hangat dapat meningkatkan sirkulasi, mengurangi edema, dan meningkatkan sirkulasi relaksasi otot. Karena panas dapat menyebabkan dilatasi pembuluh darah yang dapat mengakibatkan peningkatan sirkulasi darah (Suandika, 2015).

Selain senam kaki dan perendaman dengan air hangat, kegiatan pijat kaki didalam spa kaki diabetik juga mempengaruhi sirkulasi darah perifer. Terapi pijat refleksi kaki dapat mempengaruhi hormon tubuh yaitu dapat meningkatkan sekresi endorfin. Endorfin memiliki efek narkotika alami yaitu mengurangi rasa sakit dan meningkatkan kegembiraan. Impuls saraf yang dihasilkan Saat mendengarkan musik diteruskan menuju hipotalamus untuk menghasilkan corticotropin releasing factor (CRF). CRF tersebut akan merangsang kelenjar pituitary untuk meningkatkan produksi proopioidmelanocortin (POMC) sehingga produksi endorfin oleh medulla adrenal meningkat. Endorfin yang disekresikan ke dalam peredaran darah mempengaruhi suasana hati menjadi rileks. Endorfin menyebabkan vasodilatasi pembuluh darah sehingga terjadi penurunan tekanan darah rata-rata (Yuwono, 2015). 


\section{Analisa Perbedaan Nilai ABI Sebelum dan Setelah Intervensi pada Kelompok Intervensi 5 Hari}

Hasil analisis pada tabel 2 bahwa rata-rata nilai ABI sebelum adalah 0.8375 dan sesudah adalah 0.9625 dengan rata-rata perubahan 0.125 . Hasil uji wilcoxon diperoleh $\mathrm{p}$ value $(0.001)<\alpha(0,05)$, ada perbedaaan nilai $\mathrm{ABI}$ darah sebelum dan sesudah pada kelompok intervensi 5 hari.

Peneliitian ini sejalan dengan penelitian Affiani (2014) yang intervensi foot spa diabetic selama 5 hari pada kelompok intervesi dengan responden sebanyak 23 orang dan kelompok control tidak di berikan perlakuan sebanyak 23 orang. Hasil dari penelitian ini adalah foot spa diabetic efektif terhadap sirkulasi darah perifer. Semakin rutin dilakukannya spa kaki diabetik, maka sirkulasi darah perifer akan semakin baik, sehingga dapat mencegah komplikasi dari diabetes mellitus.

Foot spa diabetic merupakan kegiatan perawatan kaki yang diperlukan pasien diabetes secara menyeluruh untuk mencegah timbulnya ganggren dan juga perawatan terhadap pembuluh darah perifer Seperti pendapat dari Helmawati (2014) bahwa pencegahan timbulnya kaki diabetik mutlak diperlukan. Prinsip pencegahan kaki diabetes adalah menghindari terjadinya luka dan terus berupaya mengontrol keadaan gula darah. Pada spa kaki diabetik selain kegiatan senam kaki, kegiatan pembersihan (skin cleansing) dan pedicure atau pemotongan kuku dimaksudkan untuk mencegah kuku yang terlalu panjang dan masuk ke dalam sehingga dapat melukai kaki. Kegiatan foot massage merupakan rangkaian kegiatan spa kaki diabetik yang tidak kalah penting selain kegiatan senam kaki, skin cleansing, pedicure, dan foot mask.

Menurut Wicaksono (2012) dalam tubuh manusia terdapat jaringan - jaringan ke seluruh bagian tubuh yang satu dengan lainnya berhubungan. Jika salah satu titik simpul itu dipijat maka akan berhubungan dengan organ-organ tertentu. Titik saraf pada penderita diabetes melitus yaitu titik pankreas, titik ini berhubungan dengan hormon insulin, yang mempengaruhi kadar gula (glukosa) darah dalam tubuh. Ketika dilakukan penekanan pada titik refleksi di kaki khususnya titik pankreas, saraf reseptor akan bekerja dan rangsangan akan berubah menjadi aliran listrik atau bioelektrik yang akan menjalar ke otak kemudian ke pankreas, sehingga produksi hormon insulin menjadi lebih baik dan kadar gula darah dalam tubuh menjadi seimbang. Penekanan yang berulang-ulang pada daerah titik refleksi juga membuat system peredaran darah menjadi lancar karena rangsangan bioelektrik membantu menghancurkan pembekuanpembekuan di aliran darah seperti lemak, sehingga membantu menetralisir kelebihan karbohidrat didalam darah. Hal ini akan menyebabkan ABI meningkat.

Berdasarkan hasil analisa antara fakta dan teori ditas peneliti sependapat bahwa foot spa diabetic dapat meningkatkan sirkulasi darah perifer karena foot spa diabetic terdiri dari berbagai macam kegiatan yaitu senam kaki diabetik sebelum pelaksanaan spa kaki, perendaman air hangat, skin cleansing yaitu pembersihan dengan menggunakan sabun mandi bayi atau sabun mandi ph tinggi yang lembut dan ringan, pedicure yaitu pemotongan dan pengikisan kuku jika responden memiliki kuku yang sedang panjang, dan terakhir adalah foot massage yaitu pemijatan superfisial pada kaki untuk meningkatkan sirkulasi darah, semakin sering dilakukan foot spa diabetic maka sirkulasi darah perifer akan semakin baik, sehingga dapat mencegah komplikasi dari diabetes mellitus. 


\section{Analisa Perbedaan Nilai ABI Sebelum dan Setelah Intervensi pada Kelompok Intervensi 5 Hari dan 3 Hari}

Berdasarkan hasil uji mann-whitney pada rata-rata nilai abi setelah pada kelompok intervensi 3 hari dengan kelompok intervensi 5 hari diperoleh $\mathrm{P}$ value $=0.112>\alpha$ (0.05), tidak ada perbedaan yang signifikan rata-rata nilai ABI setelah pada kelompok intervensi 3 hari dengan intervensi 5 hari. Hasil dari kedua kelompok pengukuran dapat ditarik kesimpulan bahwa intervensi foot spa diabetic 5 hari dan 3 hari sama-sama efektif untuk meningkatkan nilai ABI pada pasien diabetes mellitus tipe II.

Menurut analisis peneliti intervensi foot spa diabetic 5 hari dan 3 hari dapat menjadi tindakan mandiri perawat sebagai upaya pencegahan maupun rehabilitasi bagi pasien DM Tipe II yang memiliki resiko menderita gangguan vaskularisasi perifer tungkai bawah, karena dalam prosedur tindakan terapi SPA yang dilakukan dalam penelitian ini adalah dengan melakukan kombinasi senam kaki, perendaman air hangat dengan suhu $37^{\circ} \mathrm{C}$ dan massase. Hasil penelitian yang sama juga menjelaskan bahwa rendam kaki menggunakan air hangat dapat mengakibatkan vasodilatasi darah dan melebar lumen arteri sehingga menurunkan resistensi aliran darah yang akan meningkatkan aliran darah (Chandramolesswaran \& Govardhan, 2011). Penelitian yang senada menyatakan rendam air hangat dapat menurunkan terjadinya terjadinya aterosklerosis. Hasil penelitian yang relevan menjelaskan bahwa perendaman air hangat pada seluruh tubuh dapat meningkatkan serum adiponektin dan leptin pada orang sehat (Shimodozono et al, 2011). Hasil penelitian lainnya bahwa terapi SPA dapat meningkatkan serum leptin dan tingkat adiponektin pada penderita osteoarthritis (Fiovaranti et al., 2010). Adiponektin dan leptin merupakan adipoksit-deriverat hormon yang berperan penting antara obesitas dan gangguan inflamasi. Adiponektin mengurangi baik produksi dan aktivitas sitokin inflamasi dan membantu melindungi terhadap obesitas, peradangan pembuluh darah dan perkembangan aterosklerosis.

Pada kondisi perawatan kaki diabetik menurut teori Orem tentang self care masuk dalam kemampuan pasien terhadap perawatan diri (self-care agency) masih belum bisa terlibat dalam proses perawatan diri sehingga membutuhkan terapi kebutuhan perawatan diri (therapeutic self-care demand), yaitu tindakan yang dilakukan sebagai bantuan untuk memenuhi syarat perawatan diri. Pasien DM Tipe 2 dengan resiko terjadi komplikasi kaki diabetik memerlukan kebutuhan health deviation self-care requisites termasuk kepatuhan dalam regimen pengobatan, kesadaran terhadap kemungkinan permasalahan yang muncul berhubungan dengan pengobatan dan penyesuaian diri terhadap perubahan status kesehatan dan regimen pengobatan. Dalam intervensi foot spa diabetic berdasarkan the theory of nursing system termasuk dalam partialy compensatory system yaitu merupakan suatu tindakan keperawatan dengan memberikan kompensasi sebagian kepada pasien disebabkan karena ketidakmampuan pasien dalam memenuhi tindakan keperawatan secara mandiri.

Berdasarkan hasil analisa antara fakta dan teori ditas peneliti sependapat bahwa foot spa diabetic dapat meningkatkan sirkulasi darah perifer. Tindakan kombinasi senam kaki diabetik, perendaman air hangat dan massage memiliki tujuan yang sama yakni meningkatkan sirkuasi darah. 


\section{SIMPULAN}

Foot spa diabetic selama 3 dan 5 hari efektif meningkatkan nilai ABI. Perawat praktisi dapat menggunakan foot spa diabetic sebagai terapi untuk mencegah terjadinya komplikasi kaki diabetik.

\section{SARAN}

Penelitian selanjutnya disarankan menggunakan sampel yang lebih besar dan dapat menganalisis lebih mendalam mengenai faktor-faktor confounding dan menggunakan jenis analisa data GLM-RM agar dapat mengetahui perubahan hari keberapa yang efektif terhadap perubahan nilai ABI. Hasil penelitian ini dapat lakukan dalam penerapan asuhan keperawatan pada kasus DM dalam upaya preventif terhadap faktor resiko kaki diabetik melalui kegiatan perawatan kaki.

\section{DAFTAR PUSTAKA}

Affiani (2017). Efektivitas Spa Kaki Diabetik terhadap Sirkulasi Darah Perifer pada Pasien Diabetes Mellitus Tipe 2 di Wilayah Kerja Puskesmas Wonokromo Surabaya. Jurnal Ilmiah Kesehatan, 10(1), 120-129

Ariska, A. (2019). Efektivitas Pemberian Air Rebusan Lidah Buaya (Aloe Vera) terhadap Kadar Gula Darah pada Pasien Diabetes Melitus Tipe II. Journal of Telenursing (JOTING), l(1), 157-167. https://doi.org/https://doi.org/10.31539/joting.v1i1.537

Black, J. M \& Hawks, Jane Hokanson. (2014). Keperawatan Medikal Bedah. Edisi 8, Jilid 3. Elsevier. Singapura : PT Salemba Medika

Chandramoleeswaran, P., \& Govardhan, K. (2011). Foot care through ayurdeva. International journal of research in ayurdeva \& pharmacy, 247

Fiovaranti, A., Cantarani, L., Bacarelli, M.R., Lalla, A., Ceccatelli, L., \& Blardi, P. (2010). Effect of Spa Therapy on Serum Leptin and Adiponectin Levels in Patients with Knee Osteoarthritis. Rheumatology International, 31(7), 879-882

Greenstain, B \& Diana, W. (2010). At a Glance Sistem Endokrin Edisi Kedua. Jakarta: Erlangga

Habibie. (2017). Peripheral Arterial Disease; What Should We Know ? Nasional Symposium \& Workshop "Aceh Surgery Update 2", Banda Aceh 16 - 17 September 2017

Harefa. (2011). Pengaruh Senam Kaki terhadap Sirkulasi Darah Kaki pada Pasien Diabetes Melitus di Ruang Penyakit Dalam Rsu Dr. Pirngadi Medan Tahun 2011. Tesis. Program Studi Magister Ilmu Keperawatan. USU Medan

Helmawati, T. (2014). Hidup Sehat Tanpa Diabetes. Jakarta: Notebook

International Diabetes federation. (2017). IDF Diabetes Atlas Eighth edition 2017. Isbn (vol. 8). http://doi.org/10.1017/CBO9781107415324.004

Jumari, J., Waluyo, A., Jumaiyah, W., \& Natashia, D. (2019). Pengaruh Akupresur terhadap Kadar Glukosa Darah Pasien Diabetes Melitus Tipe 2 di Persadia RS Islam Jakarta Cempaka Putih. Journal of Telenursing (JOTING), 1(1), 38-50. https://doi.org/https://doi.org/10.31539/joting.v1i1.536

Paul, D. L \& Kalen, A. (2014). Association of Diabetic Peripheral Arterial Disease and Objective-Measured Physical Activity: NHANES 2003-2004. Journal of Diabetes \& Metabolic Disorders. http://www.jdmdonline.com/content/13/1/63. Diakses pada tanggal 18 Juni 2019 
Perkeni. (2015). Konsensus Pengendalian dan Pencegahan Diabetes Melitus Tipe 2 di Indonesia 2015. Perkeni. https://doi.org/10.1017/CBO9781107415324.004

Purwanto, B. (2014). Spa Kaki Diabetesi (Layanan Estetika pada Kaki Penderita Kencing Manis). Yogyakarta: Gava Medika

Riset Kesehatan Dasar. (2013). Badan Penelitian dan Pengembangan Kesehatan Kementerian Kesehatan RI, 9 dan 121

Shimodozono, M., Matsumoto, S., Ninomiya, K., Miyata, R., Ogata, A., Etoh, S. (2011). Acute Effects of a Single Warm-Water Bath on Serum Adiponectin and Leptin Levels in Healthy Men : A Pilot Study. Int J biometeorol, 56, 933-939

Suandika. (2015). Pengaruh Rendam Kaki Air Hangat terhadap Peningkatan Sirkulasi Darah Perifer Dilihat dari Nilai Ankle Brachial Index (ABI) pada Pasien Diabetes Mellitus di Desa Purwojati Kecamatan Purwojati

Subekti, I. (2014). Neuropati Diabetik. In: Setiati S, Alwi I, Sudoyo AW, Simadibrata K M, Setyohadi B, Syam AF, editors. Buku Ajar Ilmu Penyakit Dalam. VI. Jakarta: Interna Publishing. p. 2395-9

Suyanto. (2017). Pengaruh Terapi Spa dan Senam Kaki Diabetik pada Pasien Neuropati Perifer Diabetik. Nurscope Jurnal Keperawatan dan Pemikiran Ilmiah 3(4), 29-37

Wicaksono, R. P. (2012). Faktor-Faktor yang Berhubungan dengan Kejadian Diabetes Melitus Tipe 2. Fakultas Kedokteran Universitas Diponegoro, Semarang. diunduh http://www.eprints.undip.ac.id

Yuwono. (2015). Pengaruh Terapi Pijat Refleksi Kaki terhadap Ankle Brachial Index (ABI) pada Pasien Diabetes Melitus Tipe 2. Motorik, 10(20) 